\title{
Relationship between Thyroid Hormone and Body Fat in Young Japanese
}

\author{
Toshiro NaKashima ${ }^{1)}$, Koichi IWanaGa ${ }^{2)}$, Yukito OryoJi ${ }^{11}$ \\ Hiroko NAKAYAmA ${ }^{1)}$ and Masahiko SATO ${ }^{2)}$ \\ Health Service Center Research Laboratory " and the Department of Ergonomics" \\ of Kyushu Institute of Design, Minami-ku, Fukuoka, 815 Japan
}

It is well known that excessively secreted thyroid hormone frequently reduces lipids in serum and deprives thyrotoxic patients of their body weight. On the contrary, hypothyreoidic patients show an elevated level of serum lipids and a gain in weight. Thus thyroid hormone is supposed to play an important role on body composition. It has yet to be studied, however, if a variation of thyroid hormones in a physiological range affects serum lipids and body fat. In order to make this point clear, the present experiment was designed.

\section{METHODS}

The skinfold thickness of the upper arm and subscapular area was determined on 464 Japanese college students ; 413 males (18-31, 20.5 \pm 1.8 years old) and 51 females (18-24, $19.5 \pm 1.5$ years old). The measurements were made on the right side of the body with a Minnesota caliper model calibrated to exert pressure of $10 \mathrm{gm} / \mathrm{mm}^{3}$ of jaw surface. Based on the data, body density (D) was calculated according to the method of Nagamine and Suzuki (1964) to predict how much per cent of body mass was occupied by fat (Keys and Broẑek, 1953) (D in male $=1.0913-0.00116 \times$ sum of the skinfold thickness, $D$ in female $=1.0897-0.00133 \times$ the sum, per cent distribution for fat $=457.0 / \mathrm{D}-414.2$ ).

Five months later, serum thyroid hormones and lipids were determined during a period of overnight fasting on 19 volunteer students whose bodies were composed with a high or low percentage of fat. The high and low groups were designated as A $(n=4)$ and $a(n=6)$ in males, $B(n=4)$ and $b(n=5)$ in females, respectively. Their skinfold thickness was determined again and the reliability of the resuits for fat percentage was confirmed by the underwater weight method. Statistical significance of the results was examined by student $t$ test or Cochran cox's method.

\section{RESULTS AND DISCUSSIONS}

The fat tissue of male students was $15.4 \pm 2.93 \%$ (Mean \pm SD) of body weight, which was significantly lower than that of female students, $22.4 \pm 3.59 \%$. However, the mean value of the female was lower than that we anticipated (Broẑek et al, 1953). Lean students (fat $<10 \%$ ) and the obese (fat $\geqq 20 \%$ ) among 413 males (Keys and Broẑek, 1953) were $0.3 \%$ and $7.9 \%$, respectively. On the other hand, among 51 females (Broẑek et al, 1953), the lean (fat $<20 \%$ ) were $20 \%$ and the obese (fat $\geqq 30 \%$ ) were $4 \%$. Thus, of young Japanese we examined, male had a tendency to obesity whereas female tended to emaciate. Compared to young male, young female may have more interest in keeping her body slender, as the obese female students in the present experiment reduced the fat in a relatively short term shown in Table 1. In other words, on this occasion, we believe that an effect of education with health care was seen in the young females with obesity.

The percentages of the fat tissues of the four experimental groups were shown Table 1 . That of group (B) at the day of the experiment was lowered remarkably and was almost equal to the mean value of all females initially determined. The fat of eighteen out of 19 subjects was also determined by the underwater weight method. The results by both methods were $18.9 \pm 1.25 \%$ and $19.3 \pm 1.63 \%$, respect- 
Table 1. Body fat and Lipids in serum

\begin{tabular}{|c|c|c|c|c|c|}
\hline & \multicolumn{2}{|c|}{ Fat $(\%)^{* *}$} & Total & Triglyceride & NEFA \\
\hline normal range & $1 s t^{* * *}$ & $2 \mathrm{nd}^{* * * *}$ & $\begin{array}{c}\text { Cholesterol } \\
130-250 \mathrm{mg} / \mathrm{dl}\end{array}$ & $50-170 \mathrm{mg} / \mathrm{dl}$ & $0.2-1.0 \mathrm{mEq} / 1$ \\
\hline$A(n=4)$ & $\begin{array}{l}26.2^{* * * * *} \\
\pm \\
0.218\end{array}$ & $\begin{array}{l}25.4 \\
\pm \\
1.48\end{array}$ & $\begin{array}{r}198 \\
\pm \\
25.9\end{array}$ & $\begin{array}{c}145 \\
\pm \\
45.5\end{array}$ & 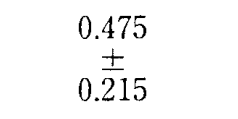 \\
\hline$B(n=4)$ & $\begin{array}{l}28.1 \\
\pm \\
1.06\end{array}$ & $\begin{array}{l}22.7 \\
\pm \\
0.156\end{array}$ & $\begin{array}{l}122 \\
\pm \\
\pm .69\end{array}$ & $\begin{array}{l}35.0 \\
\pm \\
10.7\end{array}$ & $\begin{array}{l}0.475 \\
\pm \\
0.149\end{array}$ \\
\hline$a(n=6)$ & $\begin{array}{l}10.7 \\
\pm \\
0.122\end{array}$ & $\begin{array}{c}12.1 \\
\pm \\
0.507\end{array}$ & $\stackrel{114}{ \pm} \frac{ \pm}{6.80}$ & $\begin{array}{l}48.3 \\
\pm \\
10.0\end{array}$ & $\begin{array}{l}0.483 \\
\pm \\
0.117\end{array}$ \\
\hline$b(n=5)$ & $\begin{array}{l}17.1 \\
0.594\end{array}$ & $\begin{array}{l}17.3 \\
\pm \\
0.706\end{array}$ & $\begin{array}{l}146 \\
\frac{ \pm}{14.5}\end{array}$ & $\begin{array}{l}43.0 \\
\pm \\
9.46\end{array}$ & $\begin{array}{l}0.580 \\
\pm \\
0.159\end{array}$ \\
\hline$A-B$ & & & N.S. & N.S.* & N.S. \\
\hline$A-a$ & & & $\mathrm{p}<0.01$ & N.S. & N.S. \\
\hline$A-b$ & & & N.S.* & N.S. & N.S. \\
\hline$B-a$ & & & N.S. & N.S. & N.S. \\
\hline$B-b$ & & & N.S. & N.S. & N.S. \\
\hline$a-b$ & & & N.S.* & N.S. & N.S. \\
\hline
\end{tabular}

Table 2. Serum thyroid hormone

$\begin{array}{lllllll}\mathrm{T}_{4} & \mathrm{~T}_{3} & \mathrm{rT}_{3} & \mathrm{TSH} & \mathrm{T}_{3} / \mathrm{T}_{4} & \mathrm{rT}_{3} / \mathrm{T}_{3}\end{array}$

normal range $\quad 4.5-12.5 \mu \mathrm{g} / \mathrm{dl} \quad 0.7-2.1 \mathrm{ng} / \mathrm{ml} \quad 14-39 \mathrm{ng} / \mathrm{dl} \quad 2-10 \mathrm{~m} \mu \mathrm{U} / \mathrm{ml}$

\begin{tabular}{|c|c|c|c|c|c|c|}
\hline$A(n=4)$ & $\begin{array}{c}8.98^{* *} \\
\pm \\
0.957\end{array}$ & $\begin{array}{l}1.47 \\
\stackrel{ \pm}{ \pm} \\
0.0412\end{array}$ & $\begin{array}{c}29.0 \\
\pm \\
2.04\end{array}$ & $\begin{array}{l}2.65 \\
\stackrel{ \pm}{ \pm} \\
0.210\end{array}$ & $\begin{array}{c}16.8^{*} \\
\pm \\
1.61\end{array}$ & $\begin{array}{c}198^{*} \\
\pm \\
18.7\end{array}$ \\
\hline$B(n=4)$ & $\begin{array}{c}6.80 \\
\pm \\
0.265\end{array}$ & $\begin{array}{c}0.990 \\
\stackrel{ \pm}{ \pm} \\
0.0555\end{array}$ & $\begin{array}{c}37.3 \\
\pm \\
3.68\end{array}$ & $\begin{array}{c}2.38 \\
\pm \\
0.290\end{array}$ & $\begin{array}{c}14.5 \\
\pm \\
0.837\end{array}$ & $\begin{array}{c}385 \\
\pm \\
60.1\end{array}$ \\
\hline$a(n=6)$ & $\begin{array}{r}7.80 \\
\pm \\
0.498\end{array}$ & $\begin{array}{l}1.22 \\
\pm \\
0.0665\end{array}$ & $\begin{array}{l}39.3 \\
\pm \\
2.64\end{array}$ & $\begin{array}{c}2.53 \\
\pm \\
0.156\end{array}$ & $\begin{array}{c}15.8 \\
\pm \\
1.10\end{array}$ & $\begin{array}{c}327 \\
\pm \\
26.1\end{array}$ \\
\hline$b(n=5)$ & $\begin{array}{c}6.46 \\
\pm \\
0.688\end{array}$ & $\begin{array}{l}1.01 \\
\pm \\
0.0627\end{array}$ & $\begin{array}{c}29.2 \\
\pm \\
\frac{ \pm}{3.73}\end{array}$ & $\begin{array}{c}3.92 \\
\pm \\
0.498\end{array}$ & $\begin{array}{c}16.1 \\
\pm \\
1.14\end{array}$ & $\begin{array}{c}289 \\
\pm \\
35.5\end{array}$ \\
\hline$A-B$ & N.S. & $\mathrm{p}<0.001$ & N.S. & N.S. & N.S. & $\mathrm{p}<0.05$ \\
\hline$A-a$ & N.S. & $\mathrm{p}<0.05$ & $\mathrm{p}<0.05$ & N.S. & N.S. & $\mathrm{p}<0.01$ \\
\hline$A-b$ & $\mathrm{p}<0.05$ & $\mathrm{p}<0.001$ & N.S. & $\mathrm{p}<0.05$ & N.S. & $\mathrm{p}<0.05$ \\
\hline$B-a$ & N.S. & $\mathrm{p}<0.05$ & N.S. & N.S. & N.S. & N.S. \\
\hline$B-b$ & N.S. & N.S. & N.S. & $\mathrm{p}<0.02$ & N.S. & N.S. \\
\hline$a-b$ & N.S. & $\mathrm{p}<0.05$ & $\mathrm{p}<0.05$ & $\mathrm{p}<0.02$ & N.S. & N.S. \\
\hline
\end{tabular}

$* \times 10^{-3} \quad * *$ Mean $\pm \mathrm{SE}$ 
ively and the correlation coefficient was 0.89 , indicating that the estimation by the method of skinfold thickness was fairly reliable.

Total cholesterol of group (a) was significantly lower than that of group (A). As shown in Table 1, the mean levels of total cholesterol of group (B) and (a) and those of triglyceride of group (B), (a), and (b) were apparently low. On the contrary, group (A) had a normal level of serum cholesterol and triglyceride. Nonesterified fatty acid (NEFA) showed quite normal upon testing in all groups. These resuts including those of the fat tissue imply that the nutritional state of group (B), (a), and (b) was considerably poor.

The results of $T_{4}, T_{3}$, and TSH were quite normal in all 19 subjects examined. Triiodothyronine $\left(\mathrm{T}_{3}\right)$ of male (group A and a) was significantly higher than that of female (group B and b). Thyroxine $\left(\mathrm{T}_{4}\right)$ also showed the same tendency, in a smaller extent, however. The results may suggests that slightly lowered concentration of serum thyroid hormene partly contributed to the accumulation of fat in the females of the present experiment. Therefore, variation of thyroid hormone even in a physiological range would play a role in the metabolism of fat in young subjects. Thyrotropin (TSH) of group (b) was significantly higher than that of the three other groups, probably reflecting the lowest $\mathrm{T}_{4}$. On the other hand, it is well known that monodeiodinated products of $T_{4}$, namely $T_{3}$ and $\mathrm{rT}_{3}$ well reflects the nutritional state. In starvation especially $T_{3}$ is lowered while $\mathrm{rT}_{3}$, a biologically inactive hormone is increased (Vagenakis et al, 1975). In the present experiment no significant change was observed in
$\mathrm{T}_{3} / \mathrm{T}_{4}$ ratio, whereas $\mathrm{r} \mathrm{T}_{3} / \mathrm{T}_{3}$ ratios of group (B), (a), and (b) which were thought to be in poor nutritional state were significantly higher than that of group (A). Consequently, $\mathrm{rT}_{3} / \mathrm{T}_{3}$ ratio seems to be a better and more sensitive indicator of a poor nutritional state than $T_{3} / T_{4}$ ratio.

In conclusions: 1) In young Japanese we examined, male had a tendency to obesity whereas female tended to emaciate. 2) Variation of thyroid hormone even in a physiological range might affect the volume of the fat tissue in young people. 3) The fat tissue can be reduced in a relatively short term in young subjects. 4) Reverse $\mathrm{T}_{3}\left(\mathrm{rT}_{3}\right)$ appears to respond to the nutritional state more sensitively than $T_{3}$. And $r T_{3} / T_{3}$ ratio is considered to be a good indicator for detecting slight malnutrition in comparison with $T_{3} / T_{4}$ ratio. * Supported by Grantin-Aid for Scientific Research \#58340055.

\section{REFERENCES}

Nagamine, S. and S. Suzuki, 1964 : Anthropometry and body composition of Japanese young men and women. Human Biol, 36 : 8-15.

Keys, A. and J. Broẑek, 1953: Body fat in adult man. Physiol Rev, 38 : 245-325.

Broẑek, J., K.P. Chen, W. Carlson and F. Bronczyk, 1953: Age and sex differences in man's fat content during maturity. Fed Proc, 12 : 21-22.

Vagenakis, A.G., A. Burger, G.I. Portnay, M. Rudolph, J.T. O'Brian, F. Azizi, R.A. Arky, P. Nicod, S. H. Ingbar and L.E. Braverman, 1975 : Diversion of peripheral thyroxine metabolism from activating to inactivating pathways during complete fasting. J Clin Endocr Metab, 41 : 191-194.

(Received February 16, 1984) 